\title{
Dendrodendritic Inhibition in the Olfactory Bulb Is Driven by NMDA Receptors
}

\author{
Nathan E. Schoppa, ${ }^{1}$ J. Mark Kinzie, ${ }^{1}$ Yoshinori Sahara, ${ }^{1}$ Thomas P. Segerson, ${ }^{2}$ and Gary L. Westbrook ${ }^{1}$ \\ ${ }^{1}$ Vollum Institute and 2Department of Medicine, Oregon Health Sciences University, Portland, Oregon 97201
}

At many central excitatory synapses, AMPA receptors relay the electrical signal, whereas activation of NMDA receptors is conditional and serves a modulatory function. We show here quite a different role for NMDA receptors at dendrodendritic synapses between mitral and granule cells in the rat olfactory bulb. In whole-cell patch-clamp recordings in bulb slices, stimulation of mitral cells elicited slowly decaying, GABA $_{A}$ receptor-mediated reciprocal IPSCs that reflected prolonged GABA release from granule cells. Although granule cells had a normal complement of AMPA and NMDA receptors, the IPSC was completely blocked by the NMDA receptor antagonist D,L-AP-5, suggesting that NMDA receptor activation is an absolute requirement for dendrodendritic inhibition. The AMPA receptor antagonist 1,2,3,4-tetrahydro-6nitro-2,3-dioxobenzo[f]quinoxaline-7-sulfonamide (NBQX) had no effect on IPSCs in the absence of extracellular magnesium but modestly reduced IPSCs in $1 \mathrm{~mm}$ magnesium, indicating that the primary effect of the AMPA receptor-mediated depolarization was to facilitate the unblocking of NMDA receptors. Granule cell voltage recordings indicated that effective spike stimulation in granule cells depended on the slow NMDA receptor kinetics. Granule cells also showed a pronounced delay between synaptic stimulation and action potential generation, suggesting that their intrinsic membrane properties underlie the ineffectiveness of brief AMPA receptor-mediated EPSPS. NMDA receptors also seem to have a central role in dendrodendritic inhibition in vivo, because intraperitoneal dizocilpine maleate (MK-801) injection in young adult rats resulted in disinhibition of mitral cells as measured by the generation of $c$-fos mRNA. The unique dependence of dendrodendritic inhibition on slow EPSPs generated by NMDA receptors suggests that olfactory information processing depends on long-lasting reciprocal and lateral inhibition.

Key words: olfactory bulb; dendrodendritic synapses; granule cell; mitral cell; AMPA receptor; NMDA receptor; GABA receptor; synaptic integration; dendrites
The unique circuitry of the olfactory bulb suggests that dendrodendritic synaptic interactions there have a profound influence on sensory processing (Shepherd and Greer, 1990; Scott et al., 1993). Olfactory information is mapped onto the glomerular layer of the bulb by olfactory receptor neurons that contact periglomerular cells as well as the primary dendrites of mitral and tufted cells, whose axons provide the output from the bulb. The output from the glomerular layer is transmitted by action potentials to the mitral cell soma (Bischofberger and Jonas, 1997; Chen et al., 1997) and is backpropagated into the primary and secondary dendrites to dendrodendritic synaptic contacts with periglomerular and granule cells. Because granule cells vastly outnumber mitral cells, the activation of a single mitral cell results in robust reciprocal dendrodendritic inhibition (Jahr and Nicoll, 1982). Also, a single granule cell is believed to form contacts with a large number of mitral cells, providing the mechanism for lateral inhibition of adjacent mitral cells. Thus, the temporal and spatial shaping of olfactory bulb output is strongly influenced by the amplitude and duration of dendrodendritic inhibition.

Mitral-granule cell dendrodendritic synapses are reciprocal (Rall et al., 1966; Price and Powell, 1970), consisting of an

\footnotetext{
Received April 30, 1998; revised June 10, 1998; accepted June 16, 1998.

This work was supported by National Institutes of Health Grants 5F32 DC00270-02 (N.E.S.) and NS26494 (G.L.W.).

Correspondence should be addressed to Dr. Nathan E. Schoppa, Vollum Institute, Oregon Health Sciences University, 3181 Southwest Sam Jackson Park Road, Portland, OR 97201.

Dr. Sahara's present address: Department of Physiology, Tokyo Medical and Dental University, 1-5-45, Yushima, Bunkyo-ku, Tokyo 113 Japan.

Copyright (C) 1998 Society for Neuroscience $\quad 0270-6474 / 98 / 186790-13 \$ 05.00 / 0$
}

excitatory synapse directly adjacent to an inhibitory granule-tomitral cell synapse. Aspiny mitral cell secondary dendrites contact granule cell spines in the external plexiform layer. Dendrodendritic synapses use the same transmitters and receptors that typical axodendritic synapses use, with the excitatory granule cell postsynaptic response mediated by AMPA and NMDA types of glutamate receptors (Trombley and Shepherd, 1992, 1993; Wellis and Kauer, 1994) and the inhibitory mitral cell response mediated by $\mathrm{GABA}_{\mathrm{A}}$ receptors (Nicoll, 1971; Nowycky et al., 1981; Jahr and Nicoll, 1982; Wellis and Kauer, 1993). However, the morphology of dendrodendritic synapses suggests that their activation may be atypical. For example, little is known about the mechanisms of glutamate release from dendrites. Likewise, the location of GABA release sites immediately adjacent to postsynaptic glutamate receptors suggests that GABA release from the granule cell spine could be driven by local depolarizations in the absence of action potentials (Woolf et al., 1991; Scott et al., 1993). Such factors could result in graded or prolonged dendrodendritic inhibition. Consistent with this possibility, $\mathrm{GABA}_{\mathrm{A}}$ receptormediated IPSPs on mitral cells are prolonged (e.g., Nowycky et al., 1981) compared with that on other central GABAergic synapses.

We examined dendrodendritic inhibition between mitral and granule cells using whole-cell current- and voltage-clamp recordings of synaptic responses in rat olfactory bulb slices. We also examined granule and mitral cell activation in vivo using $c$-fos mRNA as a marker of cellular activation. Our experiments indicated that dendrodendritic inhibition requires the activation of NMDA receptors, despite the fact that granule cells appear to have a normal complement of AMPA and NMDA receptors. 


\section{MATERIALS AND METHODS}

Preparation of slices. Olfactory bulb slices were prepared from 9- to 16-d-old Sprague Dawley rats that were anesthetized with halothane and then killed by decapitation. Bulbs were rapidly removed and placed in ice-cold oxygenated $\left(95 \% \mathrm{O}_{2}\right.$ and $\left.5 \% \mathrm{CO}_{2}\right)$ saline solution, which was similar to our standard recording bath solution (see below) except that 2 $\mathrm{mm} \mathrm{CaCl} 2$ was replaced with $1 \mathrm{~mm} \mathrm{CaCl}$ and $2 \mathrm{mM} \mathrm{MgCl}_{2}$. Before cutting slices, we separated the two bulbs from each other with a razor blade and glued a block that included one bulb and a small portion of the frontal cortex to a stage with cyanoacrylate glue along the ventral surface of the bulb. Horizontal slices $(400 \mu \mathrm{m})$ were cut using a vibrating microslicer (Vibratome 1000; Technical Products International, Redding, CA) and were incubated in a holding chamber for $30 \mathrm{~min}$ at $37^{\circ} \mathrm{C}$. Subsequently, the slices were stored at room temperature.

Slices were placed on an upright Zeiss Axioskop microscope with infrared (IR) differential interference contrast optics (filter, $850 \mathrm{~nm}$ ) videomicroscopy and a CCD camera (C2400; Hamamatsu, Hamamatsu City, Japan) after the standard IR filter was removed (Stuart et al., 1993). Cells were visualized with a $40 \times$ Zeiss water immersion $(0.75$ numerical aperture) lens. Mitral and granule cells could be discriminated easily on the basis of morphology (Shepherd and Greer, 1990). All experiments were done at room temperature $\left(20-24^{\circ} \mathrm{C}\right)$.

Voltage-clamp recordings. Patch seal formation and whole-cell patch recordings from mitral and granule cells in the slice were obtained using previously described methods (Stuart et al., 1993). For all experiments, the base extracellular bath solution was oxygenated $\left(95 \% \mathrm{O}_{2}\right.$ and $5 \%$ $\mathrm{CO}_{2}$ ) and contained (in mM): $125 \mathrm{NaCl}, 25 \mathrm{NaHCO}_{3}, 1.25 \mathrm{NaH}_{2} \mathrm{PO}_{4}, 25$ glucose, $2.5 \mathrm{KCl}$, and $2 \mathrm{CaCl}_{2}$, pH 7.3. Our standard bath solution contained no added $\mathrm{Mg}^{2+}$, although in some experiments, as indicated, $0.030-1 \mathrm{mM} \mathrm{Mg}^{2+}$ was added. Measurements of granule cell EPSCs were made with $50 \mu \mathrm{M}$ picrotoxin added to the bath to inhibit $\mathrm{GABA}_{\mathrm{A}^{-}}$ mediated responses (Wellis and Kauer, 1994). Granule cell miniature EPSCs (mEPSCs) were recorded also with tetrodotoxin (TTX; $1 \mu \mathrm{M}$ ) and $\mathrm{Cd}(10 \mu \mathrm{M})$ added. This concentration of Cd blocks most neuronal calcium current (Lorenzon and Foehring, 1995) without significantly affecting permeation through NMDA receptors (Mayer et al., 1989). Patch pipettes were fabricated from borosilicate glass (TW150F; WPI, Sarasota, FL) and were pulled with a conventional two-step puller (Narishige, Tokyo, Japan) to a resistance of 1-3 $\mathrm{M} \Omega$ in mitral cell recordings and 3-10 M $\Omega$ in recordings from granule cells. Mitral cell IPSC measurements were made with a pipette solution containing (in mM): $125 \mathrm{KCl}, 2 \mathrm{MgCl}_{2}, 2 \mathrm{CaCl}_{2}, 10$ EGTA, $2 \mathrm{NaATP}, 0.5 \mathrm{NaGTP}$, and 10 HEPES, adjusted to $\mathrm{pH} 7.3$ with $\mathrm{KOH}$. Granule cell EPSC measurements were made with equimolar replacement of the pipette $\mathrm{KCl}$ with $\mathrm{Cs}$ methane-sulfonate $\left(\mathrm{CsMeSO}_{4}\right)$.

Current signals recorded with an Axopatch 200A amplifier (Axon Instruments, Foster City, CA) were filtered at $1-5 \mathrm{kHz}$ using an eightpole Bessel filter and were digitized at $1-10 \mathrm{kHz}$. Data were acquired on a IBM 486 clone using PCLAMP version 6 (Axon Instruments). In all recordings, the membrane voltage $\mathrm{V}_{m}$ and the access resistance $R_{s}$ were constantly monitored. Data acquisition was terminated when $\mathrm{V}_{m}$ was more positive than $-48 \mathrm{mV}$ or $R_{s}$ obtained values $>15 \mathrm{M} \Omega$. No series resistance compensation was used, because the voltage error from the series resistance was expected to be $<10 \mathrm{mV}$ for most recordings. The reported membrane potentials were corrected for junction potentials, which were estimated to be $<8 \mathrm{mV}$, for the solutions used. The holding potential for the current recordings was between -70 and $-80 \mathrm{mV}$.

Electrical stimulation of the glomeruli was conducted with a bipolar tungsten electrode (tip separation of $200 \mu \mathrm{m}$; Frederick Haer and Company, Brunswick, ME) placed just above the slice in the glomerular layer. Stimulus pulses were generated by the computer, which triggered a stimulus isolation unit (S-100; Winston Electronics, Millbrae, CA). Maximal $100 \mathrm{~V}$ stimulation (with a duration of $100 \mu \mathrm{sec}$ ) was used, unless otherwise indicated. Focal mitral cell stimulation was done by placing a 2-3 $\mathrm{M} \Omega$ patch pipette filled with extracellular solution above the soma of a mitral cell located $150 \mu \mathrm{m}$ or less from the granule cell from which currents were recorded. Maximal $100 \mathrm{~V}$ stimulation (with a duration of $100 \mu \mathrm{sec})$ was also used for these recordings.

Drug solutions were bath-applied. Maximally effective concentrations of the drug solutions were achieved within the first few minutes after the addition of the drugs (see the drug-response time course in Fig. $2 B$ ). Washout of drugs was achieved within 5-10 min.

Drugs were obtained from the following sources: picrotoxin and TTX were from Sigma (St. Louis, MO); D,L-2-amino-5-phosphonopentanoic acid (D,L-AP-5), bicuculline, 6-cyano-7-nitroquinoxaline-2,3-dione (CNQX), $(R, S)$-3-(2-carboxypiperazin-4-yl)-propyl-1-phosphonic acid
(CPP), 2-hydroxysaclofen, and 1,2,3,4-tetrahydro-6-nitro-2,3-dioxobenzo [f]quinoxaline-7-sulfonamide (NBQX) were from Tocris (Ballwin, MO); and dizocilpine maleate (MK-801) was a gift from Merck, Sharp, and Dohme (West Point, PA).

Granule cell current-clamp recordings. Voltage recordings from granule cells were made with the current-clamp facility of the Axopatch 200A amplifier. Solutions were identical to those used in the measurements of granule cell EPSCs, with the exception of an equimolar replacement of the $\mathrm{CsMeSO}_{4}$ in the pipette with Kgluconate. Pipette resistances were 8-12 $\mathrm{M} \Omega$. In recordings from small cells like granule cells, care is required for the compensation of the pipette capacitance. In our experiments, these currents were minimized by using a shallow bath and, in some recordings, by coating the patch pipette with Sylgard; the currents were completely compensated in the cell-attached configuration. From the voltage recorded immediately after patch membrane rupture, we estimated that granule cells had an average resting potential of $-66 \pm 2$ $\mathrm{mV}(n=32)$. For the duration of the recording, a small 5-10 pA negative current was sometimes injected to hold the cell continuously at a voltage between -65 and $-75 \mathrm{mV}$. Step current injections of $10 \mathrm{pA}$ from rest yielded estimates of the membrane time constant $\tau_{m}$ (59 \pm 14 msec; $n=$ $12)$ and the input resistance $(0.98 \pm 0.17 \mathrm{G} \Omega ; n=12)$.

Data analysis and statistics. All analyses were done using AXOGRAPH (Axon Instruments) on a Macintosh computer. Estimates of the IPSC charge were made by subtracting the holding current and then numerically integrating the remaining current beginning at the time at which a stimulus was applied. The detection of IPSCs and mEPSCs was done by evaluating the error between the data and a sliding double exponential template function, with the specified time constants. For all experiments, statistical significance was determined using standard $t$ tests within Microsoft EXCEL (Redmond, WA). In the displayed histograms (see Figs. 2C, $4 C$ ), the numbers above the histogram bars reflect the number of cells for each condition. The response for each cell was the average from 10 or more stimulus-evoked IPSCs or EPSPs. Asterisks denote statistical significance.

In vivo analysis of $\mathrm{c}-\mathrm{fos} m R N A$ activation. Male Sprague Dawley rats at postnatal day $10(\mathrm{P} 10)-\mathrm{P} 12(n=2$ per treatment $)$ and P19-P21 $(n=4$ per treatment) were injected with either MK- 801 at $1 \mathrm{mg} / \mathrm{kg}$ or saline. Rats were then placed in a Buchner funnel $(160 \mathrm{~mm})$ covered by a glass funnel $(155 \mathrm{~mm})$ into which flowed charcoal-filtered, humidified air (10 $1 / \mathrm{min}$ ) for $90 \mathrm{~min}$. Filtered air or a 1:10 dilution of isoamyl acetatesaturated air $(\sim 22 \mu \mathrm{M})$ was then supplied to the chamber for $5 \mathrm{~min}$, followed by $15 \mathrm{~min}$ of filtered air. Rats were deeply anesthetized with pentobarbital and perfused transcardially with ice-cold saline followed by $4 \%$ paraformaldehyde in $0.1 \mathrm{M}$ sodium borate, $\mathrm{pH} 9.5$. The brains were removed quickly and post-fixed overnight at $4^{\circ} \mathrm{C}$ in fixation buffer containing $10 \%$ sucrose. Coronal freezing-microtome sections $(25 \mu \mathrm{m})$ of the olfactory bulb were collected, mounted onto Poly-Prep slides (Sig$\mathrm{ma}$ ), and prepared for hybridization as previously described (Kinzie et al., 1995). The probe for c-fos mRNA was generated using a $1.3 \mathrm{~kb}$ EcoRI/SacI fragment of rat $c$-fos subcloned into pGEM3z (from Dr. Philip Stork, Vollum Institute). By the use of linearized template DNA, ${ }^{35}$ S-labeled antisense probe was transcribed and hybridized on tissue sections using previously described methods (Saugstad et al., 1994; Kinzie et al., 1995). After the sections were dehydrated in increasing concentrations of ethanol, they were vacuum-dried and exposed to DuPont Cronex-4 x-ray film for $3 \mathrm{~d}$. The autoradiograms of hybridized sections were converted to digital images by a Nikon LS3500 scanner at 1670 $\operatorname{dot} / \mathrm{cm}$ resolution for manipulating in Photoshop (Adobe).

Dark-field figures and intensity measurements were taken using emulsion-dipped slides. The slides were dipped in NTB-2 liquid photographic emulsion (Eastman Kodak, Rochester, NY), exposed for $3 \mathrm{~d}$, developed with D-19 developer, and counterstained with thionin. Images were captured using a CCD camera and the National Institutes of Health Image computer program under conditions of constant intensity after the camera was calibrated to avoid supersaturating pixel intensities. Intensity quantification was performed using National Institutes of Health Image. Because granule cells are found immediately medial to the mitral cell layer, a region of interest (ROI) was drawn around mitral cells in bright-field images then restored on the corresponding dark-field image, and the mean pixel intensity of the ROI was computed. The same procedure was then taken with the granule cell layer in which the ROI was drawn medial to the internal plexiform layer.

Two control experiments were conducted to determine the specificity of the ${ }^{35} \mathrm{~S}$-antisense RNA probe. First, melting-temperature analysis of the $c$-fos probe demonstrated that the probe was removed from all cells of the 

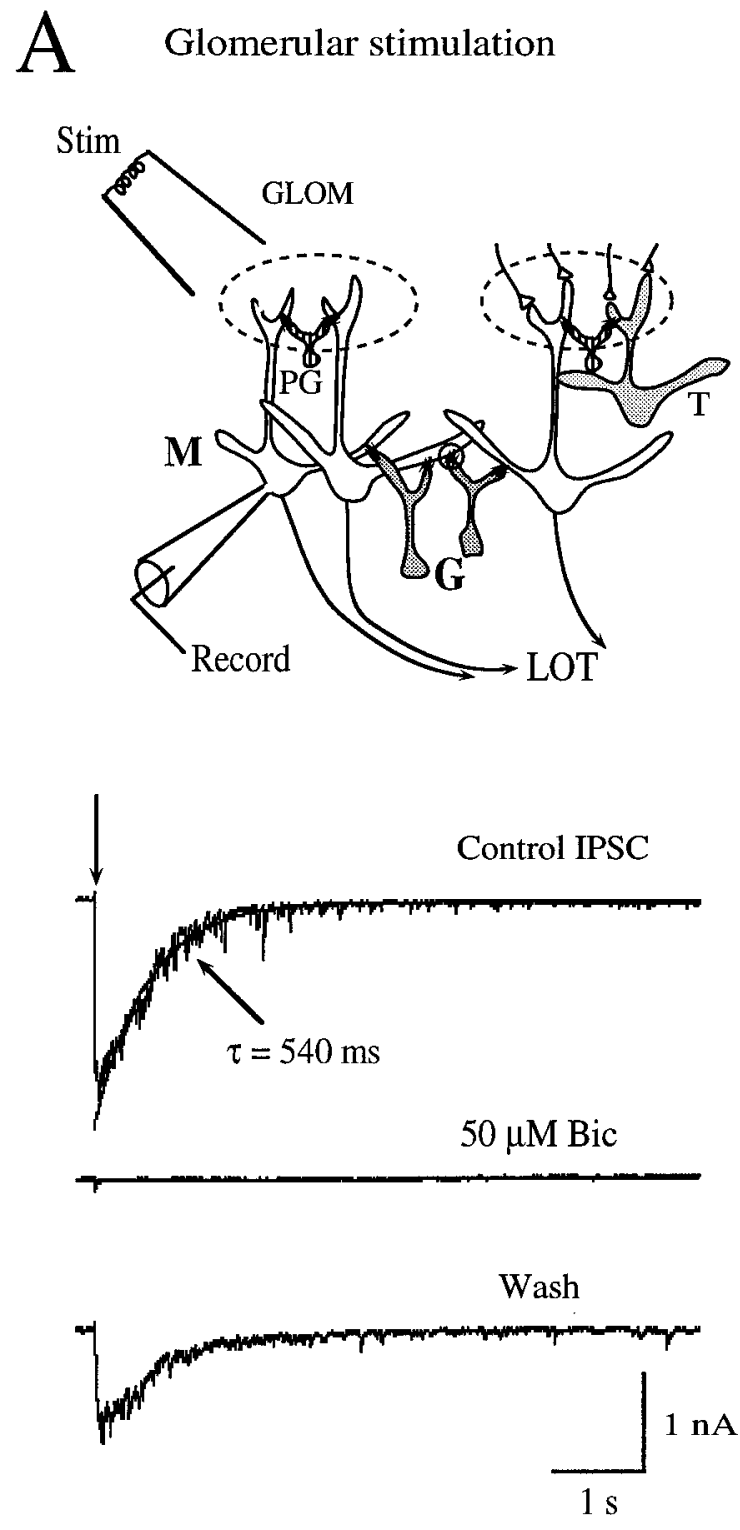

B

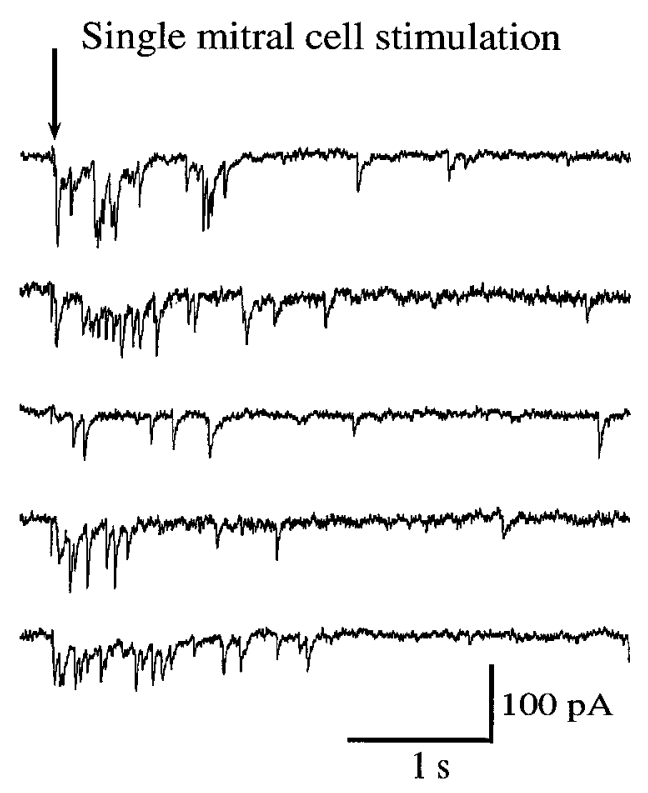

Ensemble average of composite IPSCs $(\mathrm{n}=22)$

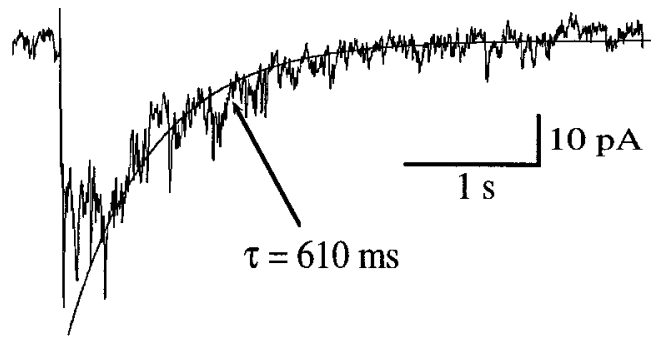

Average of detected IPSCs $(\mathrm{n}=55)$

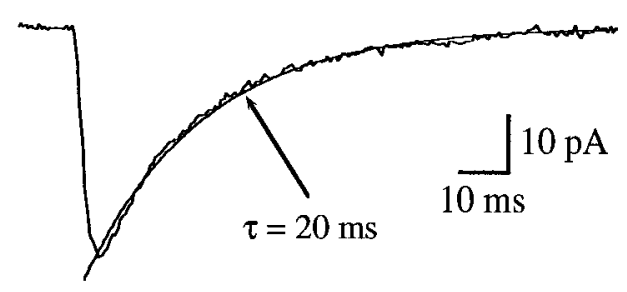

Figure 1. The kinetics of the dendrodendritic inhibition are determined by the asynchronous release of GABA from granule cells. $A$, Bipolar stimulation (Stim) in the glomerular layer $(G L O M)$ elicited a long-lasting inward current in the mitral cell $(M)$, when recordings were made with a NaCl extracellular solution with no added magnesium $(\mathrm{Control})$. The current was blocked by bicuculline $(\mathrm{Bic} ; 50 \mu \mathrm{M})$, indicating that it reflects a $\mathrm{GABA}_{\mathrm{A}}$ receptor-mediated IPSC caused by the release of GABA from granule cells $(G)$ at reciprocal dendrodendritic synapses (small circle). Data are from cell 971126 c2. In the diagram, individual glomeruli are indicated by dashed ovals; $P G$, periglomerular cells; $T$, tufted cell; $L O T$, lateral olfactory tract. $B$, Direct somatic stimulation of a mitral cell with the recording pipette also elicited an IPSC, shown here as five raw data traces (top). The traces showed unitary IPSCs with fast kinetics, but the averaged, composite IPSC (bottom) had a slow decay $(\tau=0.61 \mathrm{sec})$ like that of the IPSC elicited by glomerular stimulation The action potential-mediated sodium current was deleted from these traces for clarity. Data are from cell $97508 \mathrm{c} 4$. $C$, The average of 55 unitary IPSCs in the recording in $B$ had a decay time constant of $20 \mathrm{msec}$. Detection of unitary IPSCs was done with a template comprising rising and decaying exponentials ( $\tau$ of 3 and $30 \mathrm{msec}$, respectively).

olfactory bulb when the hybridized sections were washed in the narrow temperature range of $95-100^{\circ} \mathrm{C}$. Second, an unlabeled $c$-fos RNA probe used in 100 -fold excess blocked hybridization by the labeled $c$-fos probe.

\section{RESULTS}

The slow time course of the dendrodendritic IPSC is determined by the asynchronous release of GABA from granule cells

To activate dendrodendritic synapses in mitral cells, a bipolar electrode was placed on the surface of the slice in the glomerular layer, where olfactory nerve axons contact the primary dendrites of mitral cells (Fig. $1 A$ ). Mitral cells were voltage clamped at -70 $\mathrm{mV}$ with $\mathrm{KCl}$-containing patch pipettes. To allow full expression of glutamate receptors that might be involved in the activation of dendrodendritic synapses, we first examined synaptic responses in magnesium-free saline. Maximal glomerular stimulation (100 $\mu$ sec; $100 \mathrm{~V}$ ) elicited a large, slowly decaying inward whole-cell current. The current was completely blocked by bicuculline (Fig. $1 A ; 50 \mu \mathrm{M} ; n=7)$ or picrotoxin $(50 \mu \mathrm{M} ; n=2)$ but not by the 
$\mathrm{GABA}_{\mathrm{B}}$ receptor antagonist 2-hydroxysaclofen $(100 \mu \mathrm{M} ; n=3)$, indicating that the current was mediated by mitral cell $\mathrm{GABA}_{\mathrm{A}}$ receptors. The slow IPSCs had a peak amplitude of $1.4 \pm 0.3 \mathrm{nA}$ and a decay time constant of $0.41 \pm 0.05 \mathrm{sec}(n=18)$. The IPSC amplitude was proportional to stimulus intensity $(n=3$; data not shown). Given the $200 \mu \mathrm{m}$ tip separation of the stimulating electrode and the diameter of a single glomerulus $(130 \mu \mathrm{m})($ Scott et al., 1993), it seems likely that maximal stimulation activated the $\sim 25$ mitral cells that project to a single glomerulus (see Scott et al., 1993). TTX (1 $\mu \mathrm{M})$ blocked the IPSC, suggesting that normal afferent pathways were activated by simulation.

The prolonged IPSCs we observed are consistent with activation of reciprocal dendrodendritic synapses between mitral and granule cells (Rall et al., 1966; Nowycky et al., 1981; Jahr and Nicoll, 1982). However, activation of granule cells by mitral cell axon collaterals (Shepherd and Greer, 1990) could contaminate the dendrodendritic IPSC. To test this possibility, we recorded IPSCs in response to direct somatic stimulation of a single mitral cell in the presence and absence of TTX (Jahr and Nicoll, 1982). A 2 msec depolarization to $0 \mathrm{mV}$ applied to the mitral cell evoked an action potential that was followed by a flurry of brief inward synaptic currents (Fig. 1B). The synaptic currents were completely blocked by bicuculline $(n=8)$ or picrotoxin $(n=3)$. The ensemble average of a series of single mitral cell depolarizations produced a composite IPSC (Fig. $1 B$ ) that was smaller than the IPSC evoked in the same cell by glomerular stimulation ( $73 \pm 4 \%$ reduction; $n=17)$ but that had the same decay time course $(\tau$, $0.46 \pm 0.05$ vs $0.41 \mathrm{sec} ; n=21)$. TTX $(1 \mu \mathrm{M})$ blocked the IPSC elicited by a 2 msec depolarization $(n=7)$, but longer somatic depolarizations $(10-500 \mathrm{msec})$ evoked IPSCs $(1.2 \pm 0.4 \mathrm{nA})$ that did not differ from the IPSC before the addition of TTX $(1.1 \pm$ $0.2 \mathrm{nA}$ ). The TTX-insensitive IPSCs are likely to be dendritic in origin because mitral cell dendrites should be much more effectively depolarized than are axons by somatic voltage injections. The TTX-insensitive IPSCs, taken together with morphological data showing that only a subset of mitral cells have axon collaterals in the bulb (Orona et al., 1984), suggest that axon collaterals made little contribution to the IPSCs under our conditions.

The decay of the dendrodendritic IPSCs was much slower than was the kinetics of commonly observed stimulus-evoked $\mathrm{GABA}_{\mathrm{A}}$ receptor-mediated IPSCs (e.g., Edwards et al., 1990). The long duration of the IPSC did not seem to represent prolonged deactivation kinetics of the $\mathrm{GABA}_{\mathrm{A}}$ receptors because, as noted above, single mitral cell stimulation revealed discrete synaptic events with rapid decay time courses. In five cells, the decay time constant of the unitary IPSCs was $18 \pm 1 \mathrm{msec}$ (Fig. 1C), which is similar to that of IPSCs observed in other pathways. Likewise, direct stimulation of granule cells with a patch pipette elicited a monophasic IPSC in mitral cells that occurred with a short latency (time-to-peak from stimulus, 5.8 and $7.7 \mathrm{msec} ; n=2$ cells) and with rapid decay ( $\tau, 15$ and $22 \mathrm{msec} ; n=2$ cells). These results indicate that the slow kinetics of the dendrodendritic IPSC elicited by mitral cell stimulation reflects the prolonged and asynchronous release of GABA from granule cells.

\section{NMDA receptors, and not AMPA receptors, mediate GABA release from granule cells}

The slowly decaying IPSCs in mitral cells are driven by the excitatory synaptic response in granule cells. Most central excitatory synapses have both AMPA and NMDA receptors. Granule cells also express multiple AMPA and NMDA receptor subunits (Keinänen et al., 1990; Petralia and Wenthold, 1992; Watanabe et
A

Control IPSC

$10 \mu \mathrm{M} \mathrm{NBQX}$

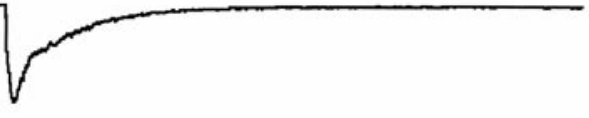

r

Wash(1)

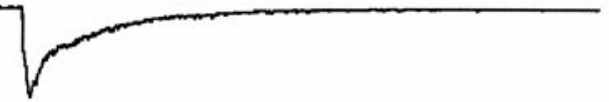

$50 \mu \mathrm{M}$ DL-APV

Wash(2)

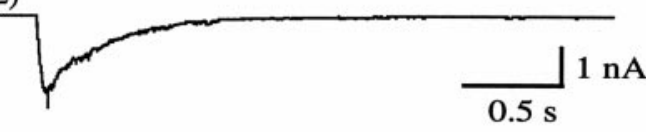

B

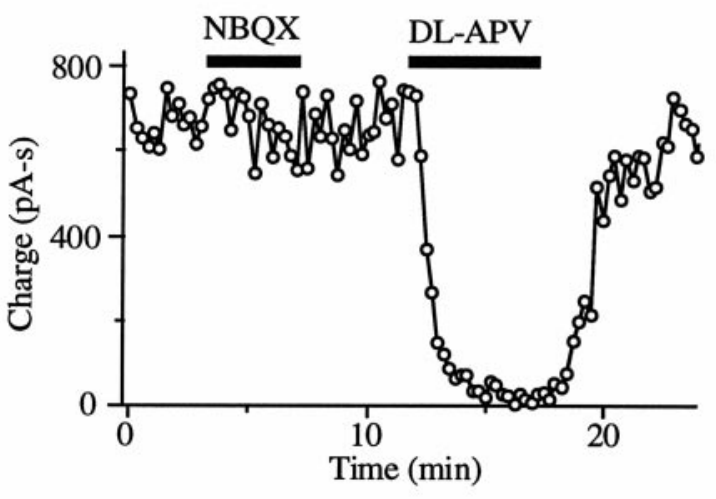

$\mathrm{C}$

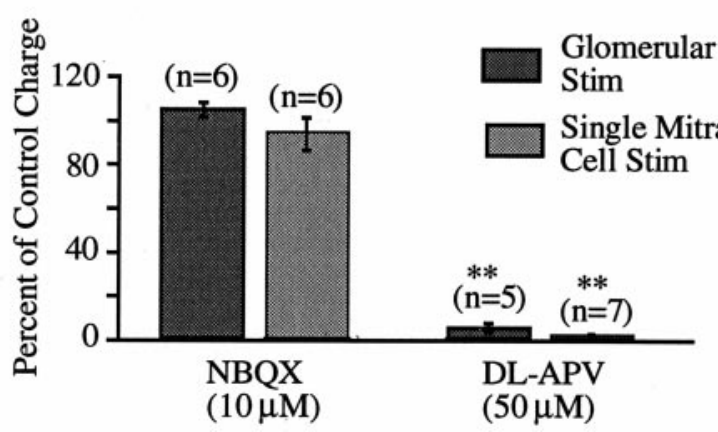

Figure 2. Dendrodendritic inhibition requires the activation of NMDA receptors. $A$, The glomerular stimulation-evoked IPSC was insensitive to the AMPA receptor antagonist NBQX $(10 \mu \mathrm{M})$ but was completely blocked by the NMDA receptor antagonist D,L-AP-5 $(50 \mu \mathrm{M})$. Each displayed trace reflects an average of 10-20 traces. Data are from cell 971016c5. $B$, The effect of D,L-AP-5 on the IPSCs in $A$ occurred rapidly and was reversible within $5 \mathrm{~min}$ after the removal of the drug. Quantification of drug effects was done by integrating the IPSC, yielding a charge value. $C$, The histogram summarizes the effects of NBQX and D,L-AP-5 on the IPSCs. Similar glutamate receptor pharmacological profiles were observed for the IPSCs evoked by glomerular stimulation and by single mitral cell stimulation.

al., 1993; Petralia et al., 1994). However, bath application of the NMDA receptor antagonist D,L-AP-5 (50-100 $\mu \mathrm{M})$ completely abolished the IPSC elicited by glomerular stimulation (Fig. $2 A, B)$, whereas the IPSC was insensitive to the AMPA receptor antagonist NBQX $(10 \mu \mathrm{M})$. The IPSCs typically displayed multiple kinetic components (Fig. $2 A$ ), but NBQX did not affect any 
of these components. The less-selective AMPA receptor antagonist CNQX $(10 \mu \mathrm{M})$ produced a $24 \pm 5 \%$ reduction in the IPSC charge $(n=7)$, consistent with its role as a glycine antagonist at NMDA receptors (Lester et al., 1989). A similar glutamate receptor antagonist profile was observed for the IPSC elicited by single mitral cell stimulation (Fig. 2C). Because single mitral cell stimulation bypasses the activation of the olfactory nerve-mitral cell synapse, the complete block by D,L-AP-5 indicates that NMDA receptors located at dendrodendritic synapses are an absolute requirement for activation of IPSCs in mitral cells.

Because EPSCs mediated by NMDA receptors typically persist for hundreds of milliseconds (McBain and Mayer, 1994), the duration of the granule cell EPSC may be responsible for the long duration of the dendrodendritic IPSC. To test this possibility, we examined the effect of the noncompetitive NMDA receptor antagonist MK-801, which can reduce the duration of NMDA receptor-mediated EPSCs by $\sim 50 \%$ (Rosenmund et al., 1993). For IPSCs elicited by single mitral cell stimulation, MK-801 (10 $\mu \mathrm{M})$ reduced the IPSC amplitude while producing a $23 \pm 12 \%$ $(n=10)$ acceleration of the decay time constant. The faster IPSC kinetics suggests that the kinetics of the granule cell NMDA receptor-mediated EPSC contributes to the long duration of the dendrodendritic IPSC.

\section{AMPA and NMDA receptors are present at dendrodendritic synapses}

Although AMPA and NMDA receptors generally are colocalized, there are several examples of "pure" NMDA receptor synapses (Dale and Roberts, 1985; Liao et al., 1995; Durand et al., 1996; Wu et al., 1996; O’Brien et al., 1997). Although granule cells have been reported to have both AMPA and NMDA components in their excitatory responses (Trombley and Shepherd, 1992; Wellis and Kauer, 1994), the disparate effects of NMDA and AMPA receptor antagonists on mitral cell IPSCs could imply that granule cells have many more NMDA receptors than AMPA receptors. To test this possibility, we recorded granule cell EPSCs in response to focal stimulation of a nearby mitral cell (Fig. $3 A$ ). The EPSCs had a short latency and displayed a fast component that was completely blocked by CNQX $(10 \mu \mathrm{M} ; \tau=5.5 \pm 1.2$ msec; $n=7)$, as well as a slow component that was blocked by D,L-AP-5 $(50 \mu \mathrm{M})$. The slow component was well described by two exponentials with time constants of $52 \pm 10$ and $343 \pm 48 \mathrm{msec}$ $(n=9)$. Glomerular stimulation typically elicited short-latency EPSCs with multiple peaks, presumably reflecting asynchrony in the release of glutamate from mitral cells (data not shown). In two cells, the mean latency to the first peak after stimulation was 6.7 and $7.0 \mathrm{msec}$, whereas the latency to all peaks averaged 27 and $17 \mathrm{msec}$. The fast components of these EPSCs were clearly blocked by NBQX ( $n=4$ cells). The peak amplitude of the NMDA component of the focally evoked EPSC was smaller than that of the AMPA component (Fig. $3 B ; I_{\mathrm{NMDA}} / I_{\mathrm{AMPA}}=0.26 \pm$ $0.05 ; n=24)$, whereas the relative current amplitudes were similar to those of other excitatory synapses (Forsythe and Westbrook, 1988; Hestrin et al., 1990; Silver et al., 1992; Jonas et al., 1993). Thus, the effectiveness of the NMDA receptor in driving dendrodendritic IPSCs is not simply because of a larger number of functional NMDA receptors.

Although the above results indicate that granule cells have both AMPA and NMDA receptors, it is possible that the receptors are segregated such that dendrodendritic inhibition is driven by pure NMDA receptor synapses, whereas the AMPA component of the evoked EPSC could reflect contributions from mitral cell axon collaterals or centrifugal fibers. Such a segregation of synapses should be apparent in mEPSCs. However, the small amplitude of pure NMDA receptor mEPSCs makes them difficult to detect (Bekkers and Stevens, 1989). To circumvent this problem, we compared evoked EPSCs with mEPSCs selected using the rapid kinetics characteristic of AMPA receptor-mediated mEPSCs. As shown in Figure $3 C$ (left), mEPSCs selected in this way showed a prominent NMDA receptor-mediated slow component. If the evoked EPSC reflects a composite of different populations of synapses, including pure NMDA receptor synapses, the ensemble average of these mEPSCs should have a smaller NMDA component than does the evoked EPSC because our mEPSC selection criteria excluded pure NMDA receptor-mediated mEPSCs. However, the averaged mEPSCs and the evoked current had the same decay time course (Fig. $3 C ; n=2$ ), suggesting that most synapses on one granule cell have a similar complement of AMPA and NMDA receptors.

\section{NMDA receptor activation causes stronger granule cell excitation than AMPA receptor activation}

At conventional central synapses, the depolarization caused by AMPA receptor-mediated EPSPs drives the short-latency response of the postsynaptic cell. The failure of AMPA receptors to activate dendrodendritic inhibition, despite the presence of typical dual-component EPSCs, suggests that granule cells process incoming excitatory signals in a distinctive manner. One possibility is that the short duration of the AMPA receptor-mediated EPSC limits the voltage response of granule cells. We examined this issue directly in current-clamp recordings in granule cells using potassium gluconate-containing patch pipettes. The amplitude and duration of the evoked EPSP as well as the fraction of stimuli that elicited action potentials were used as measures of the effectiveness of incoming mitral cell activity.

Glomerular stimulation $(100 \mathrm{~V} ; 100 \mu \mathrm{sec})$, identical to that used to record IPSCs in Figure 1, evoked dual-component EPSPs (Fig. $4 A, B)$ with large peak amplitudes and slow decay kinetics $(18 \pm 2$ $\left.\mathrm{mV} ; t_{1 / 2}=204 \pm 24 \mathrm{msec} ; n=21\right)$. D,L-AP-5 $(50 \mu \mathrm{M})$ had a variable effect on the peak EPSP amplitude, with an average reduction of $32 \pm 18 \%(n=7)$, but blocked stimulus-induced action potentials in all cells tested (Fig. $4 A, C$ ). In some cells, the peak of the remaining AMPA EPSP component was as large as that of the dual-component EPSP, but the AMPA component nevertheless failed to elicit spiking [Fig. $4 A, B($ top $)$ ]. D,L-AP-5 reduced the duration of the EPSPs by $62 \pm 8 \%(n=7)$, leaving an AMPA component that had a decay time constant similar to the membrane time constant $\left(\tau=62 \pm 15\right.$ and $\tau_{m}=59 \pm 14 \mathrm{msec}$, respectively; $n=12$ ), as expected for the voltage response to a fast-decaying current input. In contrast, NBQX $(10 \mu \mathrm{M})$ did not affect the peak amplitude or duration of the EPSP. Furthermore, the remaining NMDA receptor-mediated EPSP was just as effective at eliciting action potentials as was the dual-component response (Fig. 4C). These results indicate that AMPA receptors are less effective at eliciting granule cell excitation than are NMDA receptors, despite their similar amplitudes.

We next considered whether the longer duration of the NMDA receptor-mediated EPSP was critical for granule cell excitation. One clue to this possibility was their long latency to action potential firing. Even with suprathreshold dual-component depolarizations, there was a pronounced delay (72 $\pm 14 \mathrm{msec} ; n=7$ cells) before the onset of action potentials, as seen in the responses to five stimuli in Figure $4 A$. This suggests that the AMPA receptormediated EPSP was not of sufficient duration to elicit an action 

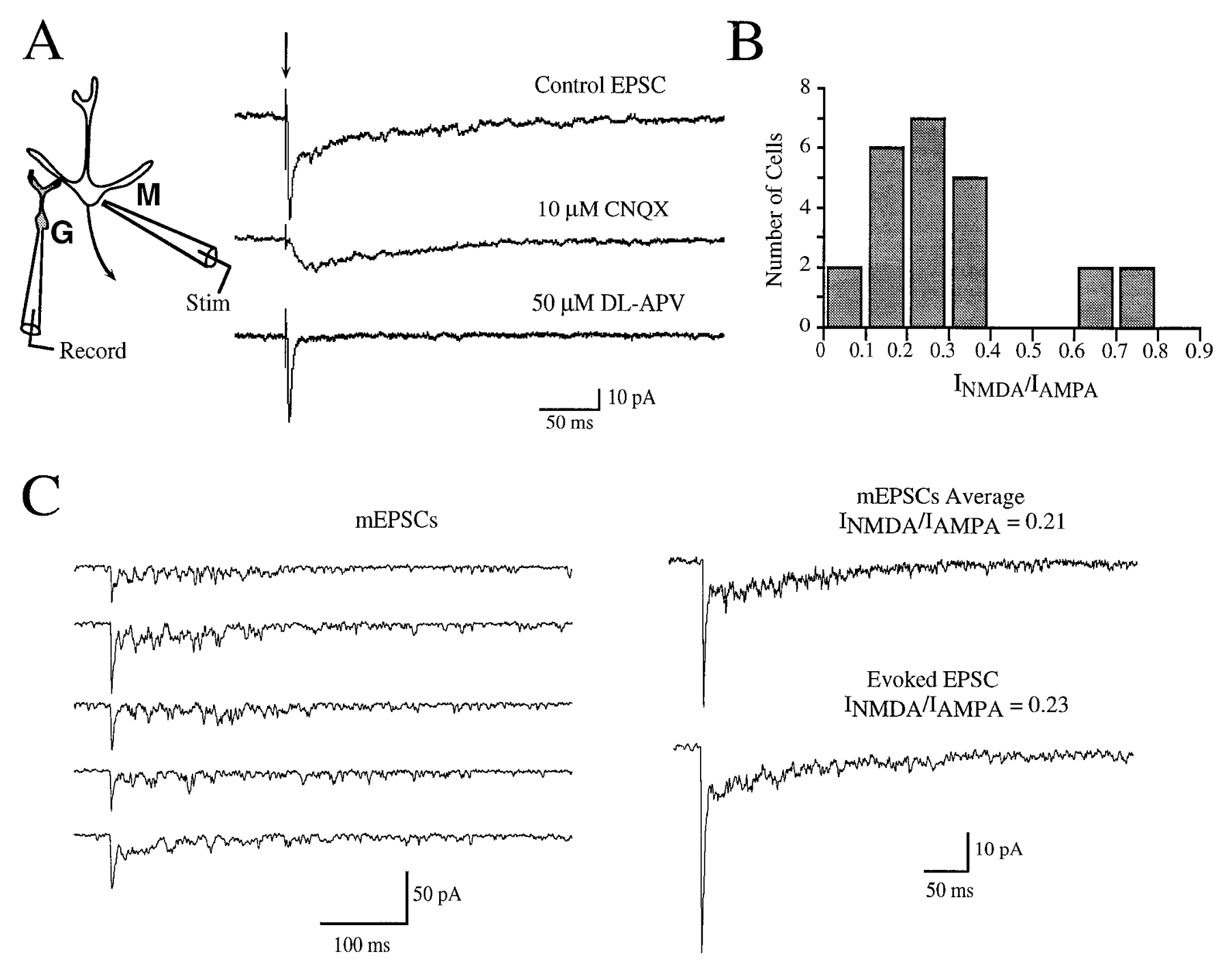

Figure 3. Granule cells have both AMPA and NMDA receptors at dendrodendritic synapses. $A$, Focal mitral cell $(M)$ stimulation $($ Stim $)$ evoked EPSCs in a granule cell $(G)$ with a CNQX-sensitive, rapidly decaying AMPA receptor-mediated component, as well as a D,L-AP-5-sensitive, slowly decaying NMDA component. The extracellular solution contained no added magnesium. Data are from cell 97617c4. $B$, The amplitude of the NMDA component was, on average, approximately one-fourth that of the AMPA component. In 24 cells, the ratio of the NMDA and AMPA receptor-mediated currents $\left(I_{\mathrm{NMDA}} / I_{\mathrm{AMPA}}\right)$ was taken from the peak current $\left(I_{\mathrm{AMPA}}\right)$ and the mean current $20-25 \mathrm{msec}$ after stimulus $\left(I_{\mathrm{NMDA}}\right)$. $C$, mEPSCs in granule cells were recorded in TTX $(1 \mu \mathrm{M})$ and cadmium $(10 \mu \mathrm{M})$. Five examples from one cell are shown $($ left $)$ that were detected using a template that approximated an AMPA mEPSC: a sum of two exponentials with rising and decay components ( $\tau$ of 0.3 and 3 msec, respectively). The averaged mEPSCs (top right; $n=15$ ) had the same time course as the evoked EPSC in the same cell (bottom right), implying that there are few pure NMDA synapses (see Results). Data are from cell $97812 \mathrm{c3}$.

potential, although the peak amplitude of the AMPA component in this cell was "suprathreshold." Short somatic current injections (2-5 msec; 50-100 pA; $n=3$ ) were similarly ineffective. The depolarizations induced by these current pulses were larger than those elicited by long current injections (400-500 msec; $10-20$ pA) that were effective in generating spikes. Thus, the granule cell membrane appears to have an intrinsic shunt that prevents action potential firing in response to a short-duration current input.

Although the complete block of EPSP-evoked action potentials in granule cells by D,L-AP-5 matched the block of the dendrodendritic IPSCs in mitral cells, this correlation does not imply that NMDA receptor-driven action potentials are required for dendrodendritic inhibition. For example, as discussed above, IPSCs could be elicited by single mitral cell stimulation in the presence of TTX. However, natural odorant stimulation does elicit action potentials in granule cells (Wellis and Scott, 1990), as did the same glomerular stimulation that elicited the IPSCs in our experiments. In 11 of 18 granule cells, glomerular stimulation drove action potentials in at least $20 \%$ of the trials. Interestingly, dendrodendritic inhibition evoked by both natural stimuli and glomerular stimulation involves both reciprocal and lateral components. Action potentials should markedly augment the dendritic spread of a voltage signal in the granule cell, which may be particularly important for lateral inhibition (Woolf et al., 1991; Scott et al., 1993).

\section{Dendrodendritic inhibition in the presence of extracellular magnesium}

Our experiments thus far have shown that NMDA receptor activation is required for dendrodendritic inhibition. However, no 

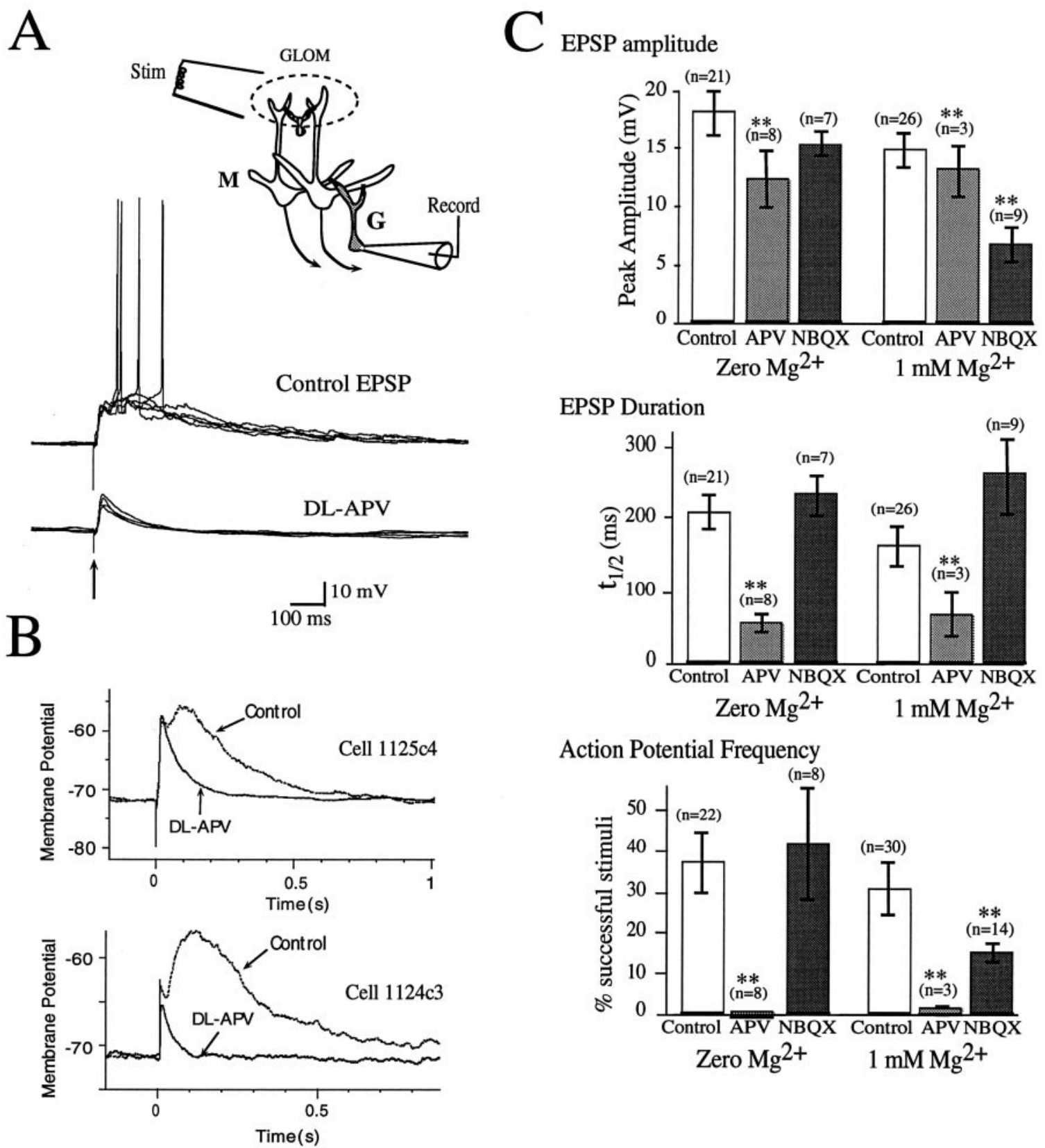

Figure 4. Stimulus-evoked action potentials in granule cells require NMDA receptor activation. A, Glomerular (top; GLOM) stimulation (Stim) evoked large dual-component EPSPs in granule cells $(G)$, as well as action potentials. Action potentials were abolished by D,L-AP-5 (bottom; $50 \mu \mathrm{M})$. Five responses before and after application of D,L-AP-5 for the same cell are shown superimposed. Firing under control conditions followed a delay, averaging $61 \mathrm{msec}$ in this cell in 13 trials. The bath had no added extracellular magnesium. Data are from cell $1125 \mathrm{c} 4$. In the diagram, the dashed oval delineates one glomerulus; $M$, mitral cell. $B$, For the cell in $A$, the peak of the EPSP in D,L-AP-5 (top) was similar to that of the dual-component EPSP; however, the duration, expressed as the time $t_{1 / 2}$ for $50 \%$ decay of the voltage signal from the peak, was reduced from 195 to $51 \mathrm{msec}$. In a different cell (bottom), D,L-AP-5 reduced the amplitude and duration of the EPSP. Only voltage responses that did not elicit action potentials were selected for averaging. $C$, In the absence of extracellular magnesium, D,L-AP-5 had variable effects on the EPSP amplitude (top) but consistently reduced the duration $t^{1 / 2}$ of the EPSP (middle) and the action potential-firing frequency (bottom). NBQX had little effect on the granule cell voltage responses in no magnesium but had modest effects on the EPSP amplitude and firing frequency in $1 \mathrm{~mm} \mathrm{Mg}^{2+}$.

magnesium was added to the extracellular bath in these experiments. Magnesium causes a potent voltage-dependent block of the NMDA receptor channel (Mayer et al., 1984; Nowak et al., 1984), but the addition of magnesium (30-1000 $\mu \mathrm{M})$ did not eliminate the mitral cell IPSC evoked by glomerular stimulation (Fig. 5A,B). Both the amplitude and duration of these IPSCs were reduced by $1 \mathrm{mM} \mathrm{Mg}^{2+}$; the remaining charge was $23 \pm 4 \%$ of control $(n=5)$. Furthermore, dual-component granule cell
EPSPs in $1 \mathrm{mM} \mathrm{Mg}^{2+}$ were large $(15 \pm 2 \mathrm{mV} ; n=26)$ and frequently elicited action potential firing in granule cells (Fig. $4 C)$. Thus, granule cell excitation and subsequent mitral cell inhibition in response to glomerular stimulation remain intact in the presence of physiological concentrations of magnesium.

Extracellular magnesium could nevertheless change the relative effectiveness of AMPA and NMDA receptors in mediating dendrodendritic inhibition. However, D,L-AP-5 (50 $\mu \mathrm{M})$ caused a 

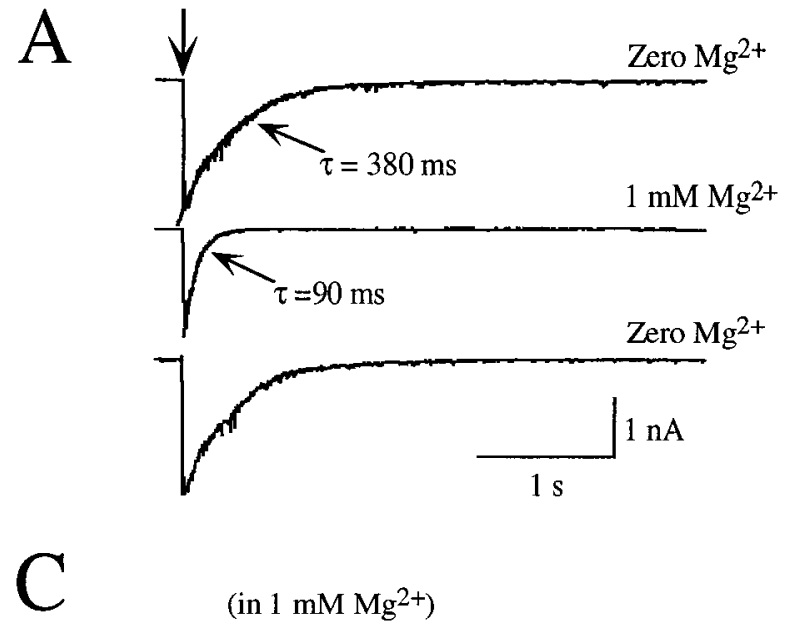

(in $1 \mathrm{mM} \mathrm{Mg}^{2+}$ )
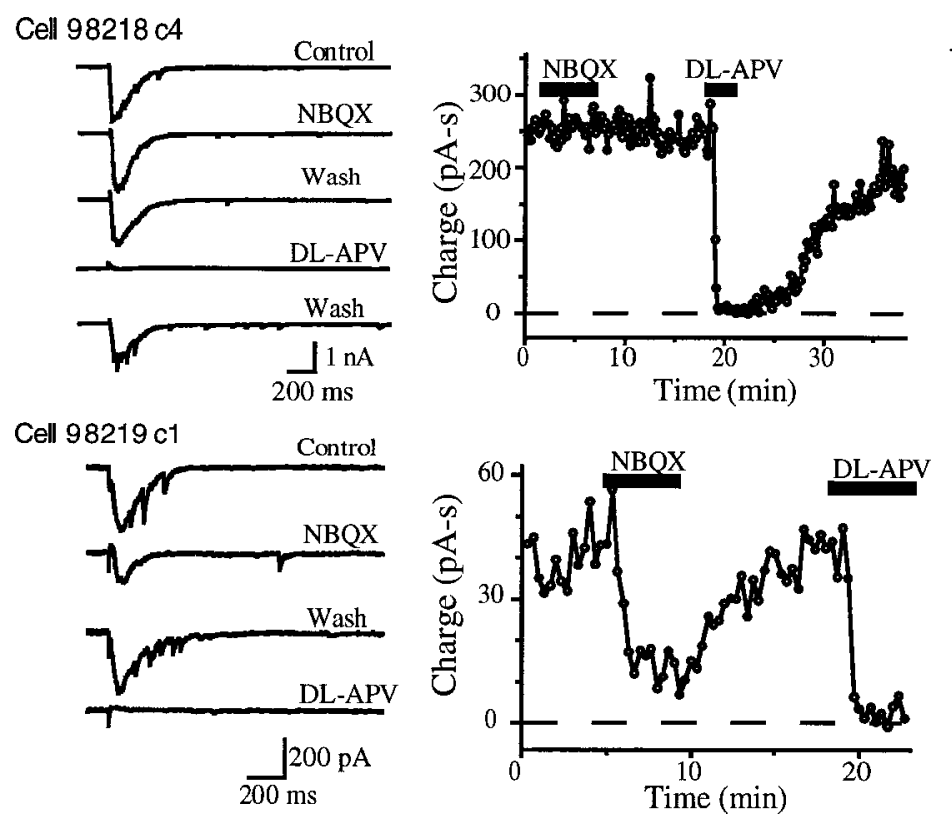

$\mathrm{D}$

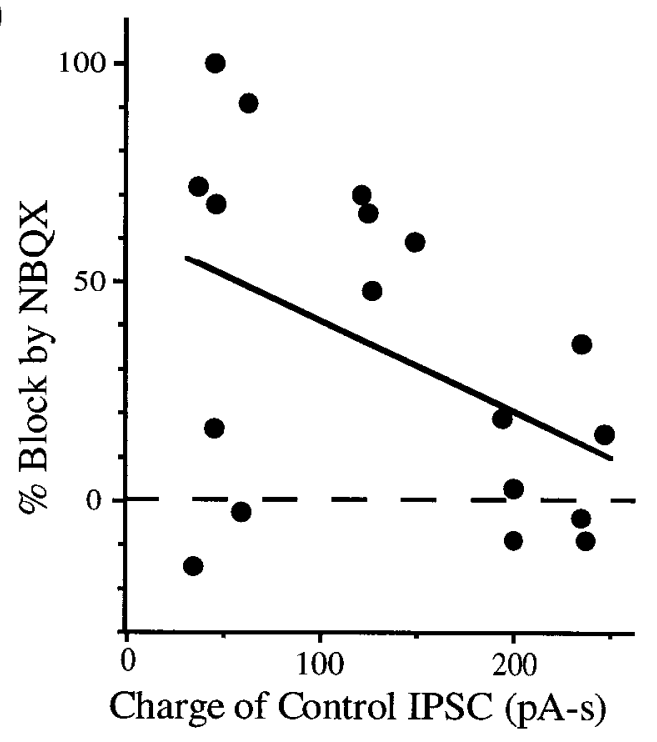

Figure 5. Mitral cell IPSCs require NMDA receptor activation in the presence of extracellular $\mathrm{Mg}^{2+} . A$, The addition of $1 \mathrm{mM} \mathrm{Mg}{ }^{2+}$ to the bath reduced the size and duration of the mitral cell IPSC evoked by glomerular stimulation. Each trace reflects the average of $8-15$ responses. Data are from cell 971103c4. B, IPSCs induced by glomerular stimulation displayed a dose-dependent blockade by magnesium ( filled circles), but $23 \%$ of the IPSC charge remained in $1 \mathrm{mM} \mathrm{Mg}^{2+}$. The magnesium-sensitivity of IPSCs evoked by single mitral cell stimulation (open circles) was markedly higher. Each plotted value reflects two to eight experiments. $C$, In the continuous presence of $1 \mathrm{mM} \mathrm{Mg}^{2+}$, IPSCs evoked by glomerular stimulation were completely blocked by D,L-AP-5 $(50 \mu \mathrm{M})$ but had varying responses to NBQX $(10 \mu \mathrm{M})$. Data from two experiments are shown. $D$, In measurements made in 18 mitral cells in magnesium, there was a modest negative correlation $(r=-0.44)$ between the size of the control IPSC and the magnitude of the NBQX effect, implying that AMPA receptors play a role in facilitating dendrodendritic inhibition under conditions of weaker stimulation.

nearly complete $(89 \pm 4 \%)$ block of mitral cell IPSC in $1 \mathrm{~mm}$ $\mathrm{Mg}^{2+}$ (Fig. 5C; $n=11$ ), with similarly large effects on granule cell excitation (Fig. 4C). The small remaining current had a rapid decay time course $(\tau=6.8 \pm 2.6 \mathrm{msec} ; n=3)$, suggesting that it was attributable to an AMPA receptor-mediated EPSC at the olfactory nerve-mitral cell synapse. In contrast to $\mathrm{Mg}^{2+}$-free conditions, NBQX $(10 \mu \mathrm{M})$ caused a modest reduction in the IPSC $(34 \pm 9 \% ; n=18)$, as well as reductions in granule cell excitability (Fig. 4C). The effect of NBQX on the IPSC was, however, highly variable, as shown for two cells in Figure $5 C$. There was a modest negative correlation $(r=-0.44 ; n=18)$ between the magnitude of the NBQX-induced block of the IPSC and the amplitude of the IPSC (Fig. 5D). These results imply that dendrodendritic inhibition in the presence of $\mathrm{Mg}^{2+}$ relies completely on the activation of granule cell NMDA receptors, whereas AMPA receptors play a facilitatory role by causing relief of the magnesium block of NMDA receptors.

The negligible effect that NBQX had on IPSCs in many cells, even in magnesium, implies that NMDA receptor activation is capable of eliciting IPSCs in the absence of AMPA receptor activation. This result was somewhat surprising given that at most central synapses, $1 \mathrm{mM} \mathrm{Mg}^{2+}$ blocks nearly all of the NMDA receptor-mediated EPSC at voltages near the granule cell resting potential $(-66 \pm 2 \mathrm{mV} ; n=32)$. However, some recombinant NMDA receptors have a reduced sensitivity to magnesium (see McBain and Mayer, 1994). To test the magnesium sensitivity of granule cell NMDA receptors, we measured granule cell EPSCs across a wide voltage range in response to focal mitral cell stimulation in the absence and presence of magnesium. The degree of block of the NMDA component attributable to $1 \mathrm{~mm}$ 


\section{CONTROL + MK 801}

Figure 6. Induction of $c$-fos mRNA in the olfactory bulb in vivo. Pseudocolored autoradiograms of in situ hybridization with an ${ }^{35} \mathrm{~S}$-antisense probe to $c$-fos mRNA were compared in four different drug and odor regimens. Coronal olfactory bulb sections from four different P21 rats are shown. Sections are oriented with dorsal $u p$ and lateral to the right. Upper left, In filtered air (ambient), only light patchy labeling was present (two blebs of highest intensity are tissue folds). Lower left, The odoractivated rat showed intense labeling of the granule cell layer $(g r)$ as well as scattered labeling in the glomerular layer $(g l)$. Upper right, In MK-801injected rats in filtered air, the mitral cell layer $(m)$ was uniformly activated. Lower right, In MK-801-injected and odor-activated rats, there was intense labeling in granule and mitral cell layers. Increased labeling of glomeruli was also apparent.

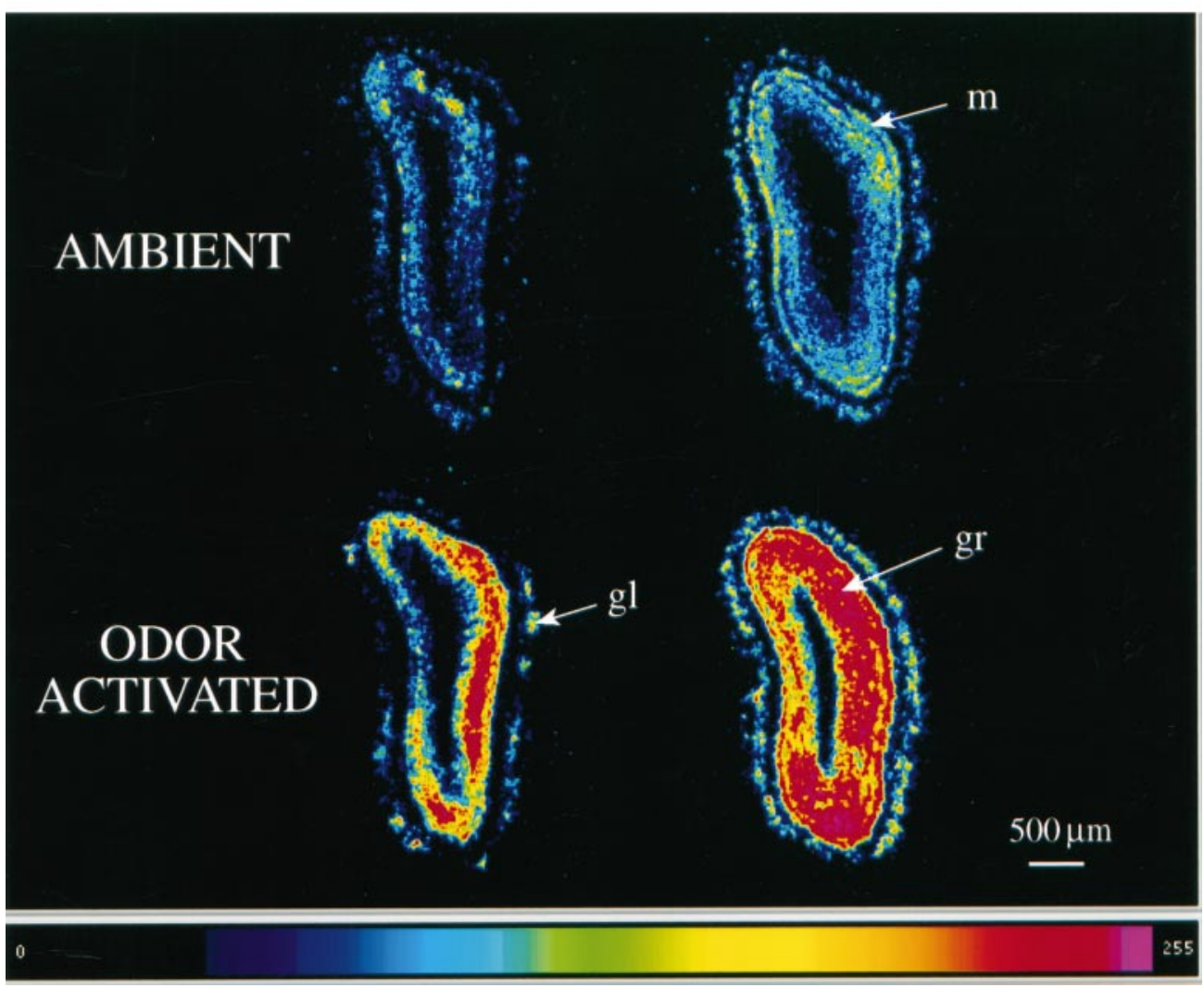

$\mathrm{Mg}^{2+}$, as estimated from the current at 30-40 msec after stimulus, was voltage-dependent, averaging $44 \pm 5 \%$ at $-28 \mathrm{mV}(n=$ 5), $78 \pm 5 \%$ at $-48 \mathrm{mV}(n=3)$, and $96 \pm 2 \%$ at $-78 \mathrm{mV}(n=$ $3)$. This block is very similar to that of the highly magnesiumsensitive receptors containing NMDAR-2A and 2B subunits (Monyer et al., 1994), as well as to the magnesium sensitivity of EPSCs at other synapses (Hestrin et al., 1990). The convergence of many mitral cells onto single granule cells, however, may provide a mechanism for relieving the magnesium block of the NMDA receptor during glomerular stimulation. Given the high input resistances of granule cells $(0.98 \pm 0.17 \mathrm{G} \Omega ; n=12)$, the activation of several mitral cell inputs should provide sufficient current through NMDA receptors to depolarize the granule cell. Consistent with such a mechanism, the block of mitral cell IPSCs elicited by glomerular stimulation was much less than that of IPSCs induced by single mitral cell stimulation (Fig. $5 B$ ). These results imply that NMDA receptors can drive dendrodendritic inhibition not because of a low intrinsic magnesium sensitivity but because of the position of the granule cell within the circuitry of the olfactory bulb.

\section{MK-801 blocks dendrodendritic inhibition in vivo}

Although the above experiments provide convincing evidence that NMDA receptor activation is required for dendrodendritic inhibition in brain slices, it is difficult to mimic precisely natural stimulation conditions in vitro. For example, the stimulus strength and other network properties of the bulb could conceivably influence the impact of voltage-dependent NMDA receptors on dendrodendritic inhibition. Thus, we examined the effects of NMDA receptor blockade on the activation of olfactory bulb circuits in 21-d-old male rats using the immediate early gene $c$-fos as a measure of cellular activation. Because $c$-fos is induced by a rise in intracellular calcium (Sheng et al., 1990), its induction has been widely used as an assay for studying the excitability of populations of neurons within many different brain regions (Morgan and Curran, 1991). Although $c$-fos mRNA expression is not a linear function of synaptic activity or action potential generation (Fields et al., 1997), it can be used to compare the relative activation of different cell groups. In particular, if NMDA receptors are required for dendrodendritic inhibition, then block of these receptors should remove inhibition and result in increased c-fos mRNA expression in mitral cells.

As seen in the low-power autoradiographs in Figure 6, the basal $c$-fos levels of rats exposed to clean air in a laminar flow apparatus ("ambient") were low with occasional glomeruli labeled, as well as patchy labeling of the granule cell layer. We then exposed rats to the general odorant isoamyl acetate (IAA) that induces $c$-fos in periglomerular and granule cells throughout the bulb (Guthrie et al., 1993). After a 5 min exposure to a 1:10 dilution of IAA, there was intense $c$-fos mRNA expression in scattered glomeruli and broad expression throughout the granule cell layer. In rats pretreated with MK-801 (1 mg/kg, i.p.), a ring of increased $c$-fos expression corresponding to the mitral cell layer was apparent under ambient air conditions, similar to that observed by Wilson et al. (1996). In addition, there was a rather uniform increase in c-fos mRNA expression in the glomerular and granule cell layers. This pattern of increased activity was even more striking in rats injected with MK-801 and exposed to IAA (Fig. 6, lower right). The expression in the granule cell layer obscured separation of the mitral cell layer at this magnification. A similar pattern was 


\section{A AMBIEnT}

\section{CONTROL}
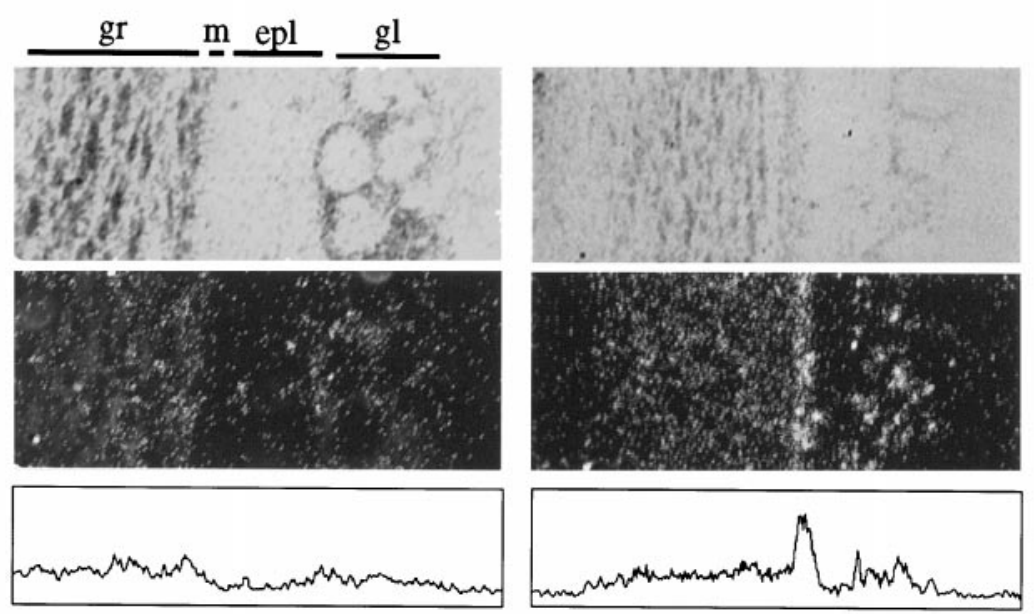

\section{B ODOR - ACTIVATED}
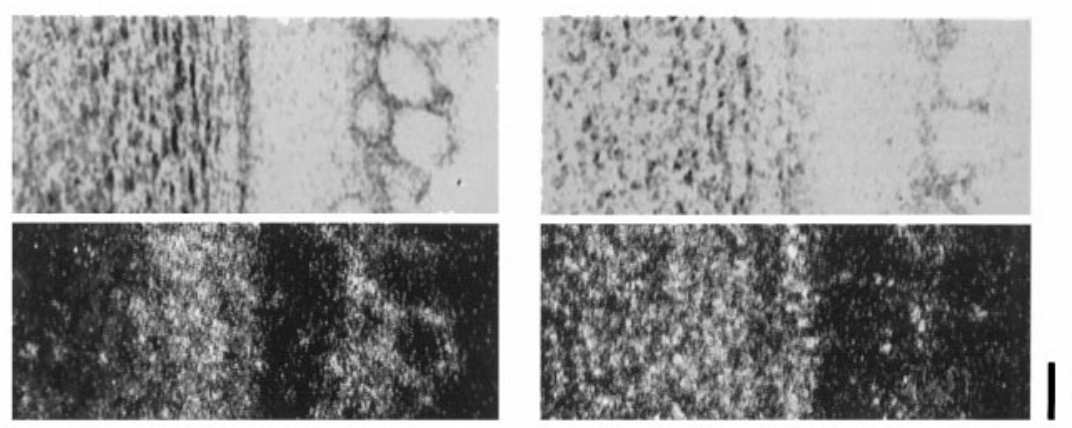

$100 \mu \mathrm{m}$
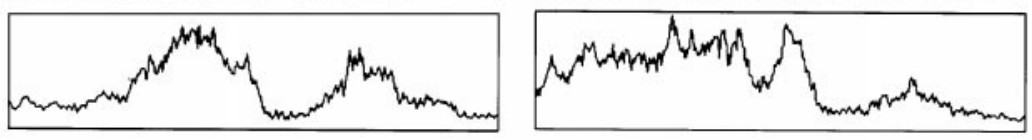

Figure 7. MK-801 increases the magnitude of $c$-fos expression in mitral cells, consistent with a reduction in dendrodendritic inhibition. Higher magnification photomicrographs of emulsiondipped slides for the filtered air $(A$, ambient) and odor-activated $(B)$ rats in Figure 6 are shown. For each condition, the top panel is a bright-field image, the middle panel is a dark-field image, and the bottom panel is a profile plot of average pixel intensity in the vertical axis of the dark-field image. Intensities from $0-150$ were plotted (total scale, $0-255)$. In filtered air, MK-801 caused a marked increase in the labeling of mitral cells $(m)$, as well as labeling of scattered tufted cells in the external plexiform layer (epl; top right). In the absence of MK-801, odor-activated rats showed labeling in the superficial half of the granule cell layer $(\mathrm{gr})$, as well as of periglomerular cells surrounding individual glomeruli in the glomerular layer $(\mathrm{gl}$; bottom left $)$. MK-801 induced a peak of intense mitral cell labeling in odor-activated rats that was not present without MK-801 (bottom right). Labeling was extended throughout the granule cell layer. Mitral cells did not stain well for thionin under the conditions used for in situ hybridization. This explains the absence of a layer of thioninstained mitral cells in the bright-field image of the bulb from rats exposed to filtered air and MK-801 (top right). observed after injection with the competitive NMDA antagonist CPP ( $n=2$; data not shown).

To examine $c$-fos mRNA expression within cell groups, we analyzed the sections shown in Figure 6 at higher magnification. Figure 7 shows bright-field and dark-field views of thioninstained, emulsion-dipped sections, along with profile plots of mean intensity values along the horizontal axis of the dark-field image. Consistent with the low-magnification views, the sections from rats exposed to ambient air and not treated with MK-801 had low levels of $c$-fos mRNA expression in granule cells and periglomerular cells. In IAA-stimulated rats, glomeruli were surrounded by $c$-fos mRNA-expressing periglomerular cells, as were granule cells in the superficial half of the granule cell layer. MK-801 produced a striking activation of cells in the mitral layer both in ambient air and after IAA stimulation. Additionally, cells in the external plexiform layer, most likely tufted cells, show higher expression of $c$-fos mRNA in MK-801. MK-801 increased the absolute level of granule cell activation as well as mitral cell activation, but this was to be expected because blocking granule cell NMDA receptors should relieve granule-cell-to-granule-cell inhibition (Wellis and Kauer, 1994). The ratio of the mean intensity values of the mitral cell layer to a layer of granule cells deep to the internal plexiform layer confirmed that MK-801 produced a significant increase in mitral cell $c$-fos expression. MK-801 increased the mitral/granule intensity ratio from $0.86 \pm$ 0.12 to $1.36 \pm 0.16$ in ambient air and from $0.47 \pm 0.01$ to $1.03 \pm$ 0.06 in odor-stimulated animals ( $n=4$, all groups). These data indicate that NMDA receptors play a key role in dendrodendritic inhibition in vivo.

\section{DISCUSSION}

The most striking features of dendrodendritic inhibition in our experiments were its prolonged duration and its absolute dependence on NMDA receptor activation. Dendrodendritic IPSCs were longer than $\mathrm{GABA}_{\mathrm{A}}$ receptor-mediated inhibition in other brain regions but are consistent with earlier studies of inhibition in mitral cells (Nowycky et al., 1981; Jahr and Nicoll, 1982; Wellis and Kauer, 1993). The IPSC duration was defined by prolonged activation of granule cells in response to mitral cell stimulation. Our results suggest that the specific properties of NMDA receptors can shape the network properties of the olfactory bulb. 


\section{Is the NMDA receptor dependence a general property of dendrodendritic synapses?}

NMDA receptors were required for triggering GABA release from granule cells, whereas AMPA receptor activation by itself was functionally ineffective. We considered several factors that could have influenced the dependence of dendrodendritic IPSCs on NMDA receptor activation in our experiments including the stimulus strength, the effects of extracellular magnesium, and the age of the animals. However, these factors did not affect the basic result. For example, in experiments done in the absence of extracellular magnesium, stimulation of a single mitral cell or many mitral cells by glomerular stimulation produced IPSCs that were completely blocked by D,L-AP-5. As expected, extracellular magnesium reduced the NMDA response in granule cells, but the remaining glomerular stimulation-evoked IPSC was still completely blocked by D,L-AP-5. On the other hand, NBQX reduced the IPSC only in magnesium-containing solutions. The magnesium dependence of the NBQX sensitivity indicates that an AMPA receptor-mediated depolarization does not trigger GABA release but instead facilitates the NMDA response by reducing magnesium block. For technical reasons, we used slices from young rats (P9-P16). Granule cell maturation and synaptogenesis are still ongoing during this period (Rosselli-Austin and Altman, 1979), and NMDA receptors may precede AMPA receptors at some synapses (Durand et al., 1996; Wu et al., 1996). However, granule cell EPSCs had both AMPA and NMDA components (see also Trombley and Shepherd, 1992; Wellis and Kauer, 1994). Likewise, the disinhibition of mitral cell $c$-fos expression by MK-801 was actually more prominent at $21 \mathrm{~d}$ than at $12 \mathrm{~d}$ (data not shown), indicating that the critical role of NMDA receptors extends at least to the young adult.

We were initially surprised that the IPSCs were completely dependent on NMDA receptor activation, although previous results did suggest that NMDA receptors are involved in dendrodendritic inhibition. For example, $\alpha$-aminoadipate, a somewhat selective NMDA antagonist, completely blocked dendrodendritic IPSCs in the turtle olfactory bulb (Nicoll and Jahr, 1982). Also, Wilson et al. (1996) found that MK-801 increased basal c-fos expression in mitral cells in rats exposed to clean air. However, incomplete block of mitral cell IPSCs by AP- 5 was observed by Wellis and Kauer (1993) in the salamander olfactory bulb. Whether species differences are significant in this regard remains unclear. Recently, Isaacson and Strowbridge (1998) reported incomplete block of mitral cell IPSCs by AP-5 in the rat bulb. However, these authors measured TTX-insensitive IPSCs in response to prolonged mitral cell depolarizations using CsCl-filled patch pipettes. The properties of glutamate release under these conditions may differ from that in our experiments.

\section{Dendrodendritic synapses compared with conventional synapses}

The critical role of NMDA receptor activation in dendrodendritic inhibition differs fundamentally from the properties of most excitatory synapses. At conventional axosomatic or axodendritic synapses, postsynaptic AMPA receptor activation is generally sufficient to drive short-latency firing of action potentials, whereas NMDA receptors require coincident depolarization or a train of depolarizations to relieve magnesium block and become fully activated. The requirement for ongoing electrical activity fits well with a modulatory role of NMDA receptors (Bliss and Collingridge, 1993). In contrast, at dendrodendritic synapses, NMDA receptors are necessary for information transfer, whereas AMPA receptors serve a facilitatory role.

Conventional axodendritic synapses do exist in which NMDA receptor activation is critical for information transfer, for example, in the thalamus, spinal cord, and cerebellum (Salt, 1986; Dickenson and Sullivan, 1990; D'Angelo et al., 1995). Dendrodendritic synapses are unusual, however, in that they are critical for action potentials as well as inhibition evoked by a single stimulus, whereas a train of stimuli are required for NMDA receptor-mediated action potentials at other synapses. The basis for this difference may be the anatomical convergence of a large number of mitral cells onto single granule cells, allowing a buildup of an NMDA response in granule cells during a single stimulus. Dendrodendritic NMDA receptors may also integrate responses to a stimulus train, as seen at other synapses.

Despite the specialized anatomical features of dendrodendritic synapses, many functional aspects of synaptic transmission appear similar to other central synapses. For example, focal mitral cell stimulation elicited fast-deactivating AMPA receptormediated EPSCs in granule cells (Fig. $3 A$ ), implying that glutamate release is brief, as observed at other fast-acting synapses (Clements et al., 1992). Focal granule cell stimulation also elicited fast-decaying IPSCs in mitral cells, suggesting that mitral cell $\mathrm{GABA}_{\mathrm{A}}$ receptors have conventional kinetics and, moreover, that the mechanics of GABA release from granule cell dendrites are conventional, given the appropriate stimulus.

\section{What is special at dendrodendritic synapses - the NMDA receptor or the granule cell response?}

Based on the properties of the granule cell EPSCs, the number of NMDA receptors or their magnesium sensitivity did not explain their preferential activation of dendrodendritic inhibition. NMDA receptors also have a high calcium permeability (Mayer and Westbrook, 1987; Ascher and Nowak, 1988), whereas most AMPA receptors including those found in bulb interneurons (Jardemark et al., 1997) have a low calcium permeability (Hollman and Heinemann, 1994). The proximity between granule cell glutamate receptors and GABA release sites on dendrodendritic synapses raises the possibility that calcium influx through NMDA receptors directly triggers GABA release. This mechanism would, however, be inconsistent with the calcium sensitivity of exocytosis at other synapses, where vesicle fusion occurs in response to $>100 \mu \mathrm{M}$ calcium within $100 \mathrm{~nm}$ of voltage-gated calcium channels (Llinas et al., 1992; Zucker, 1993). In contrast, GABA release sites on granule cell dendritic spines are up to 1 $\mu \mathrm{m}$ from the postsynaptic density (Price and Powell, 1970).

However, NMDA receptors could be located at presynaptic terminals of granule cells, as reported at some axon terminals (Berretta and Jones, 1996). Moreover, some central synapses display a slow component of transmitter release, perhaps mediated by highly calcium-sensitive protein(s) responding to residual calcium (Goda and Stevens, 1994). In principle, residual calcium derived from the NMDA receptor could mediate such a response. Although we cannot exclude the NMDA "calcium hypothesis," we favor the possibility that the calcium that triggers GABA release is derived from voltage-gated calcium channels that are preferentially opened by an NMDA receptor-mediated depolarization. The failure of TTX to block mitral cell IPSCs evoked by single mitral cell stimulation implies that action potentials are not required for this release. In the absence of action potentials, the voltage in an activated spine would be expected to be near $0 \mathrm{mV}$ (Koch and Poggio, 1983). Because such a depolarization is less 
than an action potential, a longer EPSP might be required to account for slower calcium channel-opening kinetics.

Because of the lag to action potential generation in granule cells, a prolonged NMDA receptor-mediated EPSP was also required for spiking, which might be particularly critical for lateral inhibition. The firing lag raises the possibility that an inactivating potassium conductance in the granule cell, like that reported in some other neurons (Storm, 1988; Hoffman et al., 1997; Rusznák et al., 1997), may shape the granule cell response. Thus, the intrinsic properties of the whole granule cell membrane might be better matched to a slow NMDA depolarization than to the brief AMPA receptor-mediated EPSP.

\section{Implications for olfactory processing}

The long duration of dendrodendritic IPSCs and their dependence on NMDA receptors have important implications for sensory processing in the olfactory bulb. Although the $c$-fos experiments are qualitative, they do provide a means to evaluate dendrodendritic inhibition in response to natural stimuli. The MK-801-induced enhancement of $c$-fos expression in mitral cells is consistent with a reduction of dendrodendritic inhibition. Although we did not test the effects of AMPA receptor antagonists in vivo, the disinhibition observed in MK-801 indicates that granule cell AMPA receptors drive less dendrodendritic inhibition than does NMDA receptor activation. MK-801 did not prevent the odorant-induced increase in $c$-fos expression in granule cells, indicating that AMPA receptor-mediated depolarizations resulted in sufficient calcium entry to activate $c$-fos mRNA $\left(<1 \mu \mathrm{M}\right.$ peak $\left[\mathrm{Ca}^{2+}\right]$; Fields et al., 1997); however, this calcium may not be sufficient to trigger GABA release. Only a subset of glomeruli were activated by isoamyl acetate in control animals, but there was a generalized activation of glomeruli after MK-801. The loss of spatial specificity suggests that NMDA receptor activation is critical for lateral inhibition in the glomerular layer (see also Guthrie et al., 1993). The uniform activation by odorant of the granule cell layer after MK-801 also suggests that elements of both reciprocal and lateral inhibition depend on NMDA receptors.

The properties of the NMDA response seem well adapted to influence sensory processing in the olfactory bulb. For example, their voltage dependence may insure that lateral inhibition occurs only from mitral cells that respond strongly to an odor. Spontaneously active mitral cells or those that respond weakly to an odor may not provide sufficiently robust excitation of granule cells to relieve the magnesium block of the NMDA receptor. The slow kinetics of the NMDA receptor-mediated EPSC is a major determinant of the duration of dendrodendritic IPSCs. Prolonged IPSCs are also expected to augment the spatial signal-to-noise ratio. Mitral cells can fire spontaneously at 10-20 Hz (e.g., Harrison and Scott, 1986); thus, their effective suppression requires inhibition lasting $\geq 100 \mathrm{msec}$. Prolonged IPSCs might also more effectively suppress odor-induced activity in other mitral cells, whose odor-induced spiking can be delayed or asynchronous (Hamilton and Kauer, 1989). The time course of the reciprocal inhibitory output might also be critical for the synchronized oscillatory pattern observed in odor responses (Tank et al., 1994) that have been shown in honeybees to be essential for odor discrimination (Stopfer et al., 1997).

\section{REFERENCES}

Ascher P, Nowak L (1988) The role of divalent cations in the $N$-methylD-aspartate responses of mouse central neurones in culture. J Physiol (Lond) 399:247-266.

Bekkers JM, Stevens CF (1989) NMDA and non-NMDA receptors are colocalized at individual excitatory synapses in cultured rat hippocampus. Nature 341:230-233.

Berretta N, Jones RSG (1996) Tonic facilitation of glutamate release by presynaptic $N$-methyl-D-aspartate autoreceptors in the entorhinal cortex. Neuroscience 75:339-344.

Bischofberger J, Jonas P (1997) Action potential propagation into the presynaptic dendrites of rat mitral cells. J Physiol (Lond) 504:359-365.

Bliss TVP, Collingridge GL (1993) A synaptic model of memory: longterm potentiation in the hippocampus. Nature 361:31-38.

Chen WR, Midtgaard J, Shepherd GM (1997) Forward and backward propagation of dendritic impulses and their synaptic control in mitral cells. Science 278:463-467.

Clements J, Lester RA, Tong G, Jahr CE, Westbrook GL (1992) The time course of glutamate in the synaptic cleft. Science 258:1498-1501.

Dale N, Roberts A (1985) Dual-component amino-acid mediated synaptic potentials: excitatory drive for swimming in Xenopus embryos. J Physiol (Lond) 363:35-59.

D’Angelo E, De Filippi G, Rossi P, Taglietti V (1995) Synaptic excitation of individual rat cerebellar granule cells in situ: evidence for the role of NMDA receptors. J Physiol (Lond) 484:397-413.

Dickenson AH, Sullivan AF (1990) Differential effects of excitatory amino acid antagonists on dorsal horn nociceptive neurones in the rat. Brain Res 506:31-39.

Durand GM, Kovalchuk Y, Konnerth A (1996) Long-term potentiation and functional synapse induction in developing hippocampus. Nature 381:71-75.

Edwards FA, Konnerth A, Sakmann B (1990) Quantal analysis of inhibitory synaptic transmission in the dentate gyrus of rat hippocampal slices: a patch-clamp study. J Physiol (Lond) 430:213-249.

Fields RD, Eshete F, Stevens B, Itoh K (1997) Action potentialdependent regulation of gene expression: temporal specificity in $\mathrm{Ca}^{2+}$, cAMP-responsive element binding proteins, and mitogen-activated protein kinase signaling. J Neurosci 17:7252-7266.

Forsythe ID, Westbrook GL (1988) Slow excitatory postsynaptic currents mediated by $N$-methyl-D-aspartate receptors on cultured mouse central neurones. J Physiol (Lond) 396:515-533.

Goda Y, Stevens CF (1994) Two components of transmitter release at a central synapse. Proc Natl Acad Sci USA 91:12942-12946.

Guthrie KM, Anderson AJ, Leon M, Gall C (1993) Odor-induced increases in $c$-fos mRNA expression reveal an anatomical "unit" for odor processing in olfactory bulb. Proc Natl Acad Sci USA 90:3329-3333.

Hamilton KA, Kauer JS (1989) Patterns of intracellular potentials in salamander mitral/tufted cells in response to odor stimulation. J Neurophysiol 62:609-625.

Harrison TA, Scott JW (1986) Olfactory bulb responses to odor stimulation: analysis of response pattern and intensity relationships. J Neurophysiol 56:1571-1589.

Hestrin S, Nicoll RA, Perkel DJ, Sah P (1990) Analysis of excitatory synaptic action in pyramidal cells using whole-cell recording from rat hippocampal slices. J Physiol (Lond) 422:203-225.

Hoffman DA, Magee JC, Colbert CM, Johnston D (1997) $\mathrm{K}^{+}$channel regulation of signal propagation in dendrites of hippocampal pyramidal neurons. Nature 387:869-875.

Hollman M, Heinemann S (1994) Cloned glutamate receptors. Annu Rev Neurosci 17:31-108.

Isaacson JS, Strowbridge BW (1998) Olfactory reciprocal synapses: dendritic signaling in the CNS. Neuron 20:749-761.

Jahr CE, Nicoll RA (1982) An intracellular analysis of dendrodendritic inhibition in the turtle in vitro olfactory bulb. J Physiol (Lond) 326:213-234.

Jardemark K, Nilsson M, Muyderman H, Jacobson I (1997) $\mathrm{Ca}^{2+}$ ion permeability properties of $(R, S) \alpha$-amino-3-hydroxy-5-methyl-4isoxazolepropionate (AMPA) receptors in isolated interneurons from the olfactory bulb of the rat. J Neurophysiol 77:702-708.

Jonas P, Major G, Sakmann B (1993) Quantal components of unitary EPSCs at the mossy fibre synapse on CA3 pyramidal cells of rat hippocampus. J Physiol (Lond) 472:615-663.

Keinänen K, Wisden W, Sommer B, Werner P, Herb A, Verdoorn TA, Sakmann B, Seeburg PH (1990) A family of AMPA-selective glutamate receptors. Science 249:556-560.

Kinzie JM, Saugstad JA, Westbrook GL, Segerson TP (1995) Distribution of metabotropic glutamate receptor 7 messenger RNA in the developing and adult rat brain. Neuroscience 69:167-176.

Koch C, Poggio T (1983) A theoretical analysis of electrical properties of spines. Proc R Soc Lond [Biol] 218:455-477. 
Lester RA, Quarum ML, Parker JD, Weber E, Jahr CE (1989) Interaction of 6-cyano-7-nitroquinoxaline-2,3-dione with the $N$-methyl-Daspartate receptor-associated glycine binding site. Mol Pharmacol 35:565-570.

Liao D, Hessler NA, Malinow R (1995) Activation of postsynaptically silent synapses during pairing-induced LTP in CA1 region of hippocampal slice. Nature 375:400-404.

Llinas R, Sugimori M, Silver RB (1992) Microdomains of high calcium concentration in a presynaptic terminal. Science 256:677-679.

Lorenzon NM, Foehring RC (1995) Characterization of pharmacologically identified voltage-gated calcium channel currents in acutely isolated rat neocortical neurons. I. Adult neurons. J Neurophysiol 73:1430-1442.

Mayer ML, Westbrook GL (1987) Permeation and block of $N$-methyl-Daspartic acid receptor channels by divalent cations in mouse cultured central neurones. J Physiol (Lond) 394:501-527.

Mayer ML, Westbrook GL, Guthrie PB (1984) Voltage-dependent block by $\mathrm{Mg}^{2+}$ of NMDA responses in spinal cord neurones. Nature 309:261-263.

Mayer ML, Vyklicky L, Westbrook GL (1989) Modulation of excitatory amino acid receptors by group IIB metal cations in cultured mouse hippocampal neurones. J Physiol (Lond) 415:329-350.

McBain CJ, Mayer ML (1994) N-Methyl-D-aspartic acid receptor structure and function. Physiol Rev 74:723-760.

Monyer H, Burnashev N, Laurie DJ, Sakmann B, Seeburg PH (1994) Developmental and regional expression in the rat brain and functional properties of four NMDA receptors. Neuron 2:529-540.

Morgan JI, Curran T (1991) Stimulus-transcription coupling in the nervous system: involvement of the inducible proto-oncogenes fos and jun. Annu Rev Neurosci 14:421-451.

Nicoll RA (1971) Pharmacological evidence for GABA as the transmitter in granule cell inhibition in the olfactory bulb. Brain Res 35:137-149.

Nicoll RA, Jahr CE (1982) Self-excitation of olfactory bulb neurones. Nature 296:441-444.

Nowak L, Bregestovski P, Ascher P, Herbet A, Prochiantz A (1984) Magnesium gates glutamate-activated channels in mouse central neurones. Nature 307:462-465.

Nowycky MC, Mori K, Shepherd GM (1981) GABAergic mechanisms of dendrodendritic synapses in isolated turtle olfactory bulb. J Neurophysiol 46:639-648.

O'Brien JA, Isaacson JS, Berger AJ (1997) NMDA and non-NMDA receptors are co-localized at excitatory synapses of rat hypoglossal motoneurons. Neurosci Lett 227:5-8.

Orona E, Rainer EC, Scott JW (1984) Dendritic and axonal organization of mitral and tufted cells in the rat olfactory bulb. J Comp Neurol 226:346-356

Petralia RS, Wenthold RJ (1992) Light and electron immunocytochemical localization of AMPA-selective glutamate receptors in the rat brain. J Comp Neurol 318:329-354.

Petralia RS, Wang Y-X, Wenthold RJ (1994) The NMDA receptor subunits NR2A and NR2B show histological and ultrastructural localization patterns similar to those of NR1. J Neurosci 14:6102-6120.

Price JL, Powell TPS (1970) The morphology of granule cells within the olfactory bulb. J Cell Sci 7:91-123.

Rall W, Shepherd GM, Reese TS, Brightman MW (1966) Dendrodendritic synaptic pathway for inhibition in the olfactory bulb. Exp Neurol 14:44-56.

Rosenmund C, Clements JD, Westbrook GL (1993) Nonuniform probability of glutamate release at a hippocampal synapse. Science 262:754-757.
Rosselli-Austin L, Altman J (1979) The postnatal development of the main olfactory bulb of the rat. J Dev Physiol 1:295-313.

Rusznák Z, Forsythe ID, Brew HM, Stanfield PR (1997) Membrane currents influencing action potential latency in granule neurons of the rat cochlear nucleus. Eur J Neurosci 9:2348-2358.

Salt TE (1986) Mediation of thalamic sensory input by both NMDA receptors and non-NMDA receptors. Nature 322:263-265.

Saugstad JA, Kinzie JM, Mulvihill ER, Segerson TP, Westbrook GL (1994) Cloning and expression of a new member of the L-2-amino-4phosphonobutyric acid-sensitive class of metabotropic glutamate receptors. Mol Pharmacol 45:367-372.

Scott JW, Wellis DP, Riggott MJ, Buonviso N (1993) Functional organization of the main olfactory bulb. Microsc Res Tech 24:142-156.

Sheng M, McFadden G, Greenberg ME (1990) Membrane depolarization and calcium induce $c$-fos transcription via phosphorylation of transcription factor CREB. Neuron 4:571-582.

Shepherd GM, Greer CA (1990) Olfactory bulb. In: The synaptic organization of the brain (Shepherd GM, ed), pp 133-169. New York: Oxford UP.

Silver RA, Traynelis SF, Cull-Candy SG (1992) Rapid-time-course miniature and evoked excitatory currents at cerebellar synapses in situ. Nature 355:163-166.

Stopfer M, Bhagavan S, Smith BH, Laurent G (1997) Impaired odour discrimination on desynchronization of odour-encoding neural assemblies. Nature 390:70-74.

Storm JF (1988) Temporal integration by a slowly inactivating $\mathrm{K}^{+}$current in hippocampal neurons. Nature 336:379-381.

Stuart GJ, Dodt H-U, Sakmann B (1993) Patch-clamp recordings from the soma and dendrites of neurons in brain slices using infrared video microscopy. Pflügers Arch 423:511-518.

Tank DW, Gelperin A, Kleinfeld D (1994) Odors, oscillations, and waves: does it all compute? Science 265:1819-1820.

Trombley PQ, Shepherd GM (1992) Noradrenergic inhibition of synaptic transmission between mitral and granule cells in mammalian olfactory bulb cultures. J Neurosci 12:3985-3991.

Trombley PQ, Shepherd GM (1993) Synaptic transmission and modulation in the olfactory bulb. Curr Opin Neurobiol 3:540-547.

Watanabe M, Inoue Y, Sakimura K, Mishina M (1993) Distinct distributions of five $N$-methyl-D-aspartate receptor channel subunit mRNAs in the forebrain. J Comp Neurol 338:377-390.

Wellis DP, Kauer JS (1993) GABA $_{\mathrm{A}}$ and glutamate receptor involvement in dendrodendritic synaptic interactions from salamander olfactory bulb. J Physiol (Lond) 469:315-339.

Wellis DP, Kauer JS (1994) GABAergic and glutamatergic synaptic input to identified granule cells in salamander olfactory bulb. J Physiol (Lond) 475:419-430.

Wellis DP, Scott JW (1990) Intracellular responses of identified rat olfactory bulb interneurons to electrical and odor stimulation. J Neurophysiol 64:932-947.

Wilson DA, Sullivan RM, Gall CM, Guthrie KM (1996) NMDAreceptor modulation of lateral inhibition and c-fos expression in olfactory bulb. Brain Res 719:62-71.

Woolf TB, Shepherd GM, Greer CA (1991) Local information processing in dendritic trees: subsets of spines in granule cells of the mammalian olfactory bulb. J Neurosci 11:1837-1854.

Wu G, Malinow R, Cline HT (1996) Maturation of a central glutamatergic synapse. Science 274:972-976.

Zucker RS (1993) Calcium and transmitter release at nerve terminals. Biochem Soc Trans 21:395-401. 